\title{
Indigenous People's Perception of Soil Degradation and Remediation Measures in Abia State, Nigeria.
}

\author{
Ogwo, P.A ${ }^{1}$, Ogu, O. G. ${ }^{2}$ \\ ${ }^{1}$ Department of Environmental Management \&Toxicology, Michael Okpara University of Agriculture, \\ Umudike \\ ${ }^{2}$ Department of Environmental Resource Management, Abia State University Uturu, Nigeria.
}

\begin{abstract}
A study was conducted to investigate the perceptions of indigenous people on soil degradation, causes and remediation measures employed in some selected Communities affected by soil degradation in Abia State, Nigeria. The aim was to evaluate the level of awareness of indigenes of the affected Communities on menace of soil degradation as well as the measures they adopt to combat the problem. A rapid soil degradation inventory was designed for the identification and prioritization of degraded soils in the areas using a four-point Linkert Scale. A nine-item questionnaire was distributed to selected two hundred and fifty indigenes of the affected Communities. They responded either checking low priority, priority, high priority or extremely high priority for each variable. The Linkert Scale was assigned nominal values for purposes of data transformation. Data obtained were analyzed statistically using arithmetic means, standard deviation and percentages. Results showed that $79 \%$ of respondents with the highest mean of 3.25 agreed that extremely eroded sites were due to deforestation and attendant soil loss, and was therefore ranked one. $40 \%, 34 \%, 26 \%, 24 \%, 28 \%, 20 \%$ and $22 \%$ responded positively to poor soil fertility, loss of arable farmlands, valuable economic trees and forest biodiversity, loss of means of livelihood, damage to motor able roads, pollution of nearby surface waters and increase in rural-urban migration respectively as major impacts of soil degradation in the area. Results also showed that $36 \%, 32 \%, 34 \%, 28 \%, 23.2 \%$ and $18 \%$ respectively responded to bush fallow system, use of sand filled bags, use of bamboos, terraced farming and prevention of farming within specific distance from gully sites as major prevention and control measures adopted by Communities to combat soil degradation. Results revealed that there was a high level of awareness in the Communities on the menace of soil degradation in the areas with attendant negative impacts on the well-being of the people. The use of bio-engineering techniques to combat soil degradation in the areas was recommended.
\end{abstract}

Key words: Indigenous people, perceptions, soil degradation, remediation measures, Abia State.

\section{Introduction}

Soil is a vital and indispensible environmental resource. Development, independence, food security, economic growth and sustainability of any nation depend on the functional and structural capacity of the soil. Globally, many soil sites have become unusable for agriculture, industry, commerce and human habitation due to various forms of land degradation (WRI, 1990; GLASSOD, 1987). Harris et al (1996) defined degraded soils as those soils that are no longer fit for a wide range of uses from nature systems to building sites. World's Resources Institute (WRI, 1990) defined soil degradation as the diminution of the biological productivity expected of a given tract of land. According to GLASSOD (1987), about 1.9 billion ha of land are affected by soil degradation globally. However, according to Lal (1995) degraded sites are associated with the problems of; loss of soil productivity and quality that have degenerated into derelict lands, deeply excavated sub-soils and overburden materials associated with sand, stone and mineral quarries, extremely eroded areas due to deforestation and the attendant soil loss, very barren urban landscapes with little or no vegetation and completely exposed to agents of degradation, severely compacted soils due to indiscriminate footpaths trampled by humans and roaming animals, long term spillage of used motor engine oil and lubricants in roadside mechanic workshops, soil of low productivity due to deposits of drill wastes in water boreholes and oil drilling operations, cut and fill excavation materials in roads and highway construction engineering, exposing sub-soils that no longer support vegetation growth, refuse dumpsites and other wastes in streets producing heavy metal leachates, obnoxious odours and obstructions to traffics and drainage.

The nature and scale of soil degradation vary widely among and even within Countries. The World's Soils and Terrain Digital Database has categorized land degradation as physical, chemical, biological and deforestation-induced (SOFFER, 2002). According to Lal (1995), physical soil degradation is those associated with structural decline, soil compaction, and crusting. He further reported that physical soil degradation could be due to deeply excavated sub soils and over burden materials in sand, stone and mineral quarries. Ingels (1992) identified physical soil degradation in extremely gullied areas due to excessive overland water flow that leads to 
sheet, rill and gully erosion. He further observed other physical soil degradation due to high soil temperatures resulting in soil crusting, decrease in porosity and infiltration rates and increases in bulk density and densification due to soil compaction.

Nnabude (1995) reported that chemical soil degradation were associated with leaching, nutrient imbalance and fertility depletion. According to Ademoroti (1996), accumulation of toxic substances of industrial and urban origin could contribute to chemical soil degradation. He also reported that in some intensively cultivated areas where the use of fertilizers and pesticides are high, chemical soil degradation was due to nutrient leaching, resulting in groundwater pollution and eutrophication of lakes. Omaiko et al (1983) had also reported a reduction in forage biomass production in degraded soil. They reported that biological soil degradation was associated with reduction in species diversity of soil fauna and flora, reduction in the quality and quantity of soil organic matter and changes in the climax vegetation.

Programmes of soil restoration have become necessary in order to assist the soil to recover productivity. These conventional options aimed at ameliorating soil degradation namely; bio-engineering techniques, vegetation establishment, water management through irrigation and drainage, nutrient supply by application of chemical fertilizers, grassing and organic matter management are well documented in literature. The World's Resources Institute (WRI, 1990), defines remediation as any recovery programme that is aimed at repairing and reversing the effects of degradation, which could be either abandonment or assisted recovery. Abandonment of temporarily degraded land is the basis for various types of subsistence agriculture, particularly shifting cultivation, bush fallowing, nomadic pastoralism and transhumance (Gunn, 1991). The success of abandonment at restoration depends on the principle that the fallow period must exceed the time needed for the land to recover from the tree felling, farming, grazing or other disturbances. Adding plant nutrients to a field, for example can reduce the recovery time. Assisted recovery of degraded soils can be any of rehabilitation, reclamation, remediation, amelioration or restoration. Rehabilitation is applied to areas which formerly had no growth at all, but which with careful fertilization and landscaping works may be used to grow a limited number of plant species (Harris et al, 1996). Reclamation is a process by which previously unusable land is returned to a state whereby some use may be made of it. It can also mean imputing an economic utility to lands where such utility is not natural for example converting swamp sites to farm land. Bradshaw (1984) considered reclamation as the first stage of ecological restoration of land ecosystem. At the reclamation stage, degraded soils are returned to a stage where they may be prepared for growth in function. The ecosystem at the reclamation stage is characterized by a lack of structure and nutrients but without any chemical impediment to growth such as the presence of organic contaminants. Bradshaw (1984) defined ecological restoration as a two-dimensional approach in which a degraded ecosystem is returned back to a fully functioning self-sustaining stage in both structure and function.

The United Nations Global Environmental Outlook has reported that considerable initiatives have been undertaken at the national, regional and global levels to arrest land degradation (UNEF, 1987). Such initiatives include development of monitoring and data collection methodologies, formulation of appropriate policies, programmes and projects and establishment of an institutional framework to combat land degradation. At the national level, such programmes and projects include watershed management, soil and water conservation, sand dune stabilization reclamation of water logged and saline land, forest and range management as well as green manure and cultivation of appropriate crops. Watershed management projects cover wide ranging aspects of the health of land such as farming systems; agro forestry, forest and range awareness, infrastructural development and community participation. At the International and regional levels, the United Nations Conference on Desertification was held in Nairobi in 1977 to create awareness of the serious threats to land from unsustainable exploitation and anthropogenic pressures at both national and international levels. The United Nations Environment Programme (UNEP, 1987) initiated a three-year study of the Global Assessment of Status of Human Induced Soil Degradation (GLASOD) in 1987. The GLASOD study was associated with a more detailed global soils project called the World's Soils Terrain Digital Database (SOFFER).

Bradshaw et al (1972) reported that long-term remediation of degraded soils was only by vegetation establishment through colonization of soil flora and fauna that would induce ecological succession. Vegetation establishment would increase both the structural and functional dimensions of the ecological system. Reconnaissance survey carried out in the study areas indicated that the sites were extremely eroded due to deforestation and the attendant soil loss and productivity. These sites were located at Amaiyi-Obilaohia, Oruruala and Igbere, Abia state. Soil degradation in these sites has negative impacts on the rural Communities due to diminishing level of soil fertility, loss of farmlands and forest biodiversity. These negative impacts have led to loss of arable farmlands, occupation, and means of livelihood with attendant economic hardship, and consequently increased rural-urban migration in the area. The objective of the study was to investigate the perceptions of the rural/ community dwellers on soil degradation in the area, the impact on them as well as the remediation measures they adopt at community level. 


\section{Study sites}

\section{Materials and Methods}

The study was conducted at the degraded sites in three Communities; Amaiyi-Obilaohia, Oruruala and Igbere all in Abia State, Nigeria. Amaiyi-Obilaohia and Oruruala lie on latitude $66^{0} 32^{11} \mathrm{~N}$ and longitude $8^{0} 8^{1} 52^{11} \mathrm{E}$, while Igbere lies on latitude $6^{0} 32^{1} \mathrm{~N}$ and longitude $8^{0} 6^{1} \mathrm{E}$. The areas have an annual mean rainfall of $1500 \mathrm{~mm}$ which between April and November, the annual temperature of $25^{\circ} \mathrm{C}$ and relative humidity of $65 \%$. The soil textures were mainly sandy loam. Amaiyi-Obilaohia was initially planted up with Cashew trees (Anacardium occidentale) as erosion control measure, which has suffered large scale deforestation with attendant gully erosion. The vegetation of Igbere plantation comprises of derived savannah, and was initially before the Nigeria civil war planted up with Para-rubber (Hevea- braziliensis). However, due to illegal and uncontrolled deforestation of the plantations and other vegetations, as well as bush burning and illegal sand excavation down the slope of the hills, gully erosion has developed in the site.

\section{Data Collection}

A rapid soil degradation inventory was designed for the identification and prioritization of degraded soils in areas using a four-point Linkert Scale. The method is a variant of the Participatory Learning Approaches in Environmental Impact Assessment. A nine-item questionnaire was distributed to indigenes of the areas. Two hundred and fifty people responded to the questionnaire checklist, each responded by checking either low priority (LP), high priority (HP), extremely high priority (EHP) for each variable. The Linkert Scale was assigned nominal values for purposes of data transformation. The mean score, standard deviation and percentage for each variable were calculated. Ranking of the variables was done and the site with the highest mean score was selected. Data obtained from the land degradation inventory were analyzed using arithmetic means and standard deviation, while the ranking method (low priority degraded site, priority degraded site and extremely priority degraded sites) utilized the 4-point Linkert Scale (1-4).

\section{Results and Discussion}

Table 1: Soil Degradation Impact prioritization in Abia State

\begin{tabular}{llllllll}
\hline Degradation & LP & P & HP & EHP & X & DD & PR \\
\hline $\begin{array}{l}\text { Loss of soil productivity and quality } \\
\text { that has degenerated into derelict lands }\end{array}$ & 10 & 25 & 20 & 45 & 3.2 & 0.26 & 2 \\
$\begin{array}{l}\text { Deeply excavated subsoil and overburden } \\
\text { With materials }\end{array}$ & 15 & 25 & 40 & 20 & 2.65 & - & 5 \\
Extremely eroded due to deforestation & 6 & 15 & 29 & 50 & 3.23 & 0.27 & 1 \\
And attendant soil loss & & & & & & & \\
Barren landscapes with little or no vegetation & 13 & 9 & 42 & 36 & 3.01 & - & 4 \\
Compacted due to footpath & 27 & 45 & 11 & 17 & 2.18 & - & 6 \\
Long term oil spillage & 30 & 48 & 13 & 9 & 2.01 & - & 8 \\
Soil of low productivity due to waste deposit & 25 & 52 & 18 & 5 & 2.03 & - & 7 \\
Cut and fill excavation in road construction & 49 & 19 & 21 & 11 & 1.94 & - & 9 \\
Refuse dumpsites producing leachates & 9 & 12 & 32 & 47 & 3.17 & - & 3 \\
\hline
\end{tabular}

Table 2: Impact of land degradation on rural Communities in the study areas

\begin{tabular}{llc}
\hline Impact Assessment & NO & $\begin{array}{c}\text { Respondents } \\
\%\end{array}$ \\
\hline Poor soil fertility & 100 & 40 \\
Loss of farmlands/ forest biodiversity & 85 & 34 \\
Loss of valuable forest food/fruit trees & 65 & 26 \\
Loss of occupation/means of livelihood & 60 & 24 \\
Rural-Urban Migration & 55 & 22 \\
Pollution of nearby Surface waters & 50 & 20 \\
Intensive sunlight during the rainy season & 40 & 16 \\
Too little rainfall during the rainy season & 34 & 13.6 \\
Submerged houses near gullies & 25 & 10 \\
Damage to access roads & 70 & 28
\end{tabular}


Table 3: Measures employed by rural communities to combat/rehabilitate degraded soil in the area

\begin{tabular}{lll}
\hline & \multicolumn{2}{c}{ Respondents } \\
Control Measures & Number & 32 \\
Sand filled bags & 80 & 36 \\
Bush fallow system & 90 & 18 \\
Stones arranged to prevent flooding & 45 & 34 \\
Use of bamboos for slope protection & 85 & 70 \\
Terraced farming & 20 & 8 \\
Alley cropping as vegetation strip & 58 & 23.2 \\
Prevention of farming within specific distances from gullies & 35 & 14 \\
Water harvesting (e.g. small waters catchment) & 20 & 8 \\
Water harvesting (e.g. Aluminum roof-top water channelization) & \\
\hline
\end{tabular}

\section{Discussion}

Table 1 summarizes the results of soil degradation prioritization inventory. Using the mean cut-off of 2.5 to interpret the results, the respondents noted that the variables in items 5 to 8 are not priority degraded sites in the study areas. The highest mean score of $(X=3.25)$ was recorded in questionnaire item 3 ; that is extremely eroded areas were due to deforestation and the attendant soil loss, and was therefore ranked one. Rank 9 was given to questionnaire item 8; that is cut and fill excavation materials in roads and highway construction engineering, exposing subsoil that no longer support vegetation growth $(X=1.94)$, because it had the lowest mean. The standard deviation for the item with the highest mean was 0.27 . This indicated that $79 \%$ of the respondents agreed that extremely eroded areas due to deforestation and attendant soil loss constitute extremely high priority degraded sites. It also shows that the variability or divergence of the scores from the mean score or the central value of the distribution was low. Based on the ranking of the variables, sites with extremely eroded areas due to deforestation and soil loss were selected for further investigations.

Table 2 shows the impact of land degradation on the rural Communities. Results showed that diminishing soil fertility, loss of arable farmlands and forest biodiversity due to unsustainable farming systems and gully erosion have generally led to rural-urban migration and displacement of the farming population. $40 \%$ of the respondents responded positively to poor soil fertility, while $34 \%, 26 \%, 24 \%$ and $28 \%$ responded to loss of farmlands, loss of valuable forest biodiversity and economic trees, loss of means of livelihood and damage to major roads as part of the major impacts. $20 \%$ responded to the impact of land degradation being extended to pollution of nearby streams, while $22 \%$ responded to increase in rural-urban migration as a result of land degradation in the areas. Thus, the population structure during site visit to the study sites showed that the villages consisted more of aged people and children, indicating that the young people have migrated to the cities. $10 \%$ of respondents showed that gully erosion has devastated and submerged some houses, thereby rendering the occupants homeless.

Table 3 summarizes the measures employed by rural communities to combat land degradation impacts at the study sites. About $36 \%$ responded to bush fallow system as a measure of soil remediation in the areas, while $32 \%, 34 \%, 28 \%, 23.2 \%$ and $18 \%$ respectively to the use of sand filled bags, use of isolated clumps of bamboos, terraced farming, prevention of farming within specific distance (about $300 \mathrm{~m}$ ) from gully and the use of stones arranged to prevent flooding as the major remediation measures in the areas. $8 \%$ and $14 \%$ responded to the use of alley cropping as vegetation strip and water harvesting practices respectively.

\section{Conclusion}

Results showed that sites with extremely eroded areas due to deforestation and the attendant soil loss were extremely high priority degraded sites in the study areas. Results revealed that soil degradation in the study sites has negative impact on the rural communities due to diminishing level of soil fertility, loss of arable farmlands and forest biodiversity. The negative impacts have led to loss of occupation and means of livelihood and consequently increased rural-urban migration especially the young people. Bush fallow systems/abandonment of degraded sites, sand filled bags followed by the use of isolated clumps of bamboo trees to allow for natural ecosystem and soil fertility restoration and to intercept floods and runoffs are the most prominent measures utilized by the communities to combat land degradation. These negative impacts if not checkmated could increase soil bulk density, reduce soil porosity and infiltration of water into the soil as well as increase flooding and surface runoffs with attendant gully erosion. The study therefore recommends the use of biological control methods (e.g. use of plants) in combination with engineering methods to provide costeffective solutions to increased soil erosion and many other environmental problems associated with infrastructural development in the areas. Bio-engineering is applicable in areas such as the three study sites, where topography, geology and climate are such that the areas are susceptible to landslides and soil erosion that may occur naturally or may be induced by anthropogenic activities. 


\section{References}

[1]. Ademoroti, C.M.A. (1996). Environmental Chemistry and Toxicology. Foludex Press Ltd, Ibadan, pp. $171-182$.

[2]. Bradshaw, A.D. and Smith, R.A.H. (1972). Stabilizations of Toxic Mine Waste by the use of tolerant plant populations. Trans. Inst. Min. Metal. 81:230-237.

[3]. Bradshaw, A.D., Roberts, R.D., Marrs, R.H., Skeffington, R.A. and Owen, L.D.C. (1984). The importance of plant nutrients in the restoration of China clay and other mine wastes. Trans. Inst. Min. Metall., 91:42-50

[4]. GLASOD (1987). Study of the Global Assessment of Status of Human-Induced Soil

[5]. Degradation, (GLASOD) United Nations Environment Programme, GLOBAL Environment Outlook, 1987, Nairobi Kenya.

[6]. Gunn, A.S. (1991). The restoration of species and natural environment. Environ. Ethics, 13:291-300.

[7]. Harris, J.A., Birch, P. and Palmer, J. (1996). Land Restoration and Reclamation: Principles and Practice, Longman England.

[8]. Ingels, J.E. (1992). Landscaping: Principles and Practices, Longman England.

[9]. Lal, R. (1995). Sustainable Management of Soil Resources in the Humid Tropics, United Nations University Press, Japan.

[10]. Nnabude, P.C. (1995). Physico-chemical properties and productivity of a typic haplustult in Soils of eastern Nigeria amended with rice mill wastes. PhD Thesis, University of Nigeria, Nsukka.

[11]. Omaiko, C.P.E. and Agbim N.N. (1983). Forage corn response to rice mill wastes and fertilizers. Journal of Environmental Quality, $12: 320-324$.

[12]. SOFTER (2002). World's Soils and Terrain Digital Database (SOFTER). In our Planet Magazine for sustainable development. 16(5), UNEP Nairobi, Kenya.

[13]. UNEF (1987). Global Environment Outlook, 1987 UNEP Nairobi, Kenya

[14]. WRI (1990). Participatory Rural Appraisal Handbook Washington, DC; Center for

[15]. International Development and Environment, World Resources Institute. 